\title{
MITOS NYI RORO KIDUL DALAM KEHIDUPAN MASYARAKAT CIANJUR SELATAN
}

\author{
Oleh Irvan Setiawan \\ Balai Pelestarian Sejarah dan Nilai Tradisional Bandung \\ Jln. Cinambo No. 136 Ujungberung Bandung \\ Email: kamaliasetiawan@yahoo.co.id
}

\begin{abstract}
Abstrak
Nyi Roro Kidul adalah legenda yang sangat populer pada masyarakat di Pulau Jawa. Sebagian masyarakat hingga saat ini masih percaya terhadap wilayah kekuasaan Nyi Roro Kidul di sepanjang laut selatan Pulau Jawa berikut kekuatan gaib yang dapat memberikan ketentraman ataupun sebaliknya pada masyarakat. Dua hal tersebut ditanggapi masyarakat dalam bentuk pelaksanaan upacara penghormatan, tidak melanggar pantangan.

Masyarakat Cianjur Selatan dengan wilayah administratif tepat berada di sepanjang pantai Kabupaten Cianjur adalah sebagaimana halnya masyarakat di sepanjang pantai Pulau Jawa yang juga melaksanakan ritual penghormatan kepada Nyi Roro Kidul berikut perilaku yang diupayakan sebisa mungkin untuk tidak melanggar pantangan Nyi Roro Kidul. Meski melakukan perilaku sama namun masyarakat di Cianjur Selatan tentu ada beberapa perbedaan dalam menanggapi keberadaan sosok penguasa laut selatan tersebut.
\end{abstract}

Kata Kunci: Nyi Roro Kidul, mitos.

\begin{abstract}
Nyi Roro Kidul is a real popular legend at public in Java island. Some of the existing finite publics still believing to power region of Nyi Roro Kidul alongside south sea Java island following occult strength of which can give peace and or on the contrary at public. Two the things answered to public in the form of execution of respect ceremony, doesn't impinge abstention.

Public north Cianjur with acurate administrative territory resided in coast wise Cianjur district is as also to public alongside coast Java island which also executes ritual respect to Nyi Roro Kidul following behavior strived can be be possible not to impinge abstention Nyi Roro Kidul. Even does same behavior but public in north Cianjur of course there are some difference in answering to existence of the south sea power figure.
\end{abstract}

Keywords: Nyi Roro Kidul, myth.

\section{A. Pendahuluan}

Mitos Nyi Roro Kidul sebagai penguasa pantai selatan Pulau Jawa seakan tidak pernah habis termakan usia. Benar atau tidaknya adalah bukan sebuah pernyataan yang penting karena terdapat 
perbedaan pandangan antara dunia logika, agama dan kepercayaan. Dikatakan demikian karena menurut pandangan logika bahwa segala bentuk gaib sebenarnya merupakan kumpulan energi yang terjadi pada beberapa tempat tertentu serta memancarkan kekuatan untuk membangkitkan sesuatu obyek. Agama (Islam) memang menyebutkan bahwa ada dunia jin yang mendampingi dunia manusia. Pengertian mendampingi dapat berarti membantu atau mengganggu manusia. Hampir sama halnya dengan pandangan agama, kepercayaan yang kerap dikaitkan dengan mitos memandang bahwa dunia gaib itu juga ada dan memiliki pengaruh sangat besar dalam kehidupan manusia baik dalam lingkungan keseharian, pekerjaan, ataupun keimanan. Perbedaan dengan pandangan agama bahwa terdapat banyak variasi mahluk halus dalam dunia kepercayaan disertai dengan istilah berbeda karena disesuaikan dengan kondisi kebahasaan masyarakat setempat.

Percaya atau rasa ingin tahu terhadap dunia mahluk halus tergantung dari kondisi pemikiran manusia. Namun, rasa keingintahuan menjadi faktor utama yang menggugah rasa seseorang untuk menguak tabir yang selama ini masih menutupi apa dibalik kejadian atau gejala alam di sekitar lingkungan mereka. Bencana alam, kurang beruntung, ingin sukses, dan sebagainya adalah bagian dari kehidupan manusia.

Penggunaan metode logika seringkali terbentur pada kesulitan melaksanakan proses untuk mengubah sesuatu menjadi lebih baik, aman, dan sukses. Metode supranatural adalah cara yang dianggap mumpuni dan cukup mudah dilakukan untuk mencapai tujuan tersebut. Dengan melakukan proses ritual tertentu, sebagian masyarakat merasa mendapat perlindungan dari penguasa gaib wilayah mereka.
Kondisi geografis daerah Jawa Barat berkontur pegunungan dan pantai dimanfaatkan masyarakat untuk melakukan mendapatkan penghasilan dari keuntungan geografis tersebut. Lahan di daerah pegunungan dimanfaat-kan untuk menanam sayuran, tanaman hias, dan sebagainya. Sementara itu, daerah pantai dihuni sebagian besar nelayan yang jelas mengambil keuntungan dari kekayaan lautan yang ada di bagian selatan dan utara wilayah jawa barat.

Kaitan tradisi ritual yang ada di dua wilayah pantai jawa barat (selatan dan utara) dengan mitos tentang nyi roro kidul sangat menarik untuk disimak karena pantai utara jawa barat tidak disebutkan sebagai wilayah kekuasaan Nyi Roro Kidul. Wilayah selatan pantai Jawa Barat, yaitu Sukabumi, Cianjur, Garut, Tasikmalaya, dan Ciamis, pun tidak semua yang memiliki tradisi kuat terhadap mitos Nyi Roro Kidul. Sepengetahuan penulis, ada dua wilayah yaitu Cianjur, dan Ciamis dengan pelabuhan ratu/pangandaran yang kuat memegang teguh mitos nyi roro kidul Terlangkahi oleh wilayah Tasikmalaya dan Garut menyebabkan sebuah pertanyaan mengapa masyarakat Cianjur kerap menjalankan tradisi upacara nyalawena, syukur pasisiran, dan sebagainya sebagai bagian dari proses ritual penghormatan kepada Nyi Roro Kidul.

Berdasarkan latar belakang penelitian ini, permasalahan yang timbul adalah seputar:

1. Upacara apa saja yang merupakan wujud dari penghormatan terhadap Nyi Roro Kidul pada masyarakat di wilayah Cianjur Selatan,

2. Keberadaan Nyi Roro Kidul di Cianjur Selatan apakah sebuah mitos atau fakta?

Maksud dilaksanakan penelitian ini adalah mendeskripsikan kepercayaan 
terhadap Nyi Roro Kidul pada masyarakat di pantai selatan Kabupaten Cianjur, tepatnya di wilayah pantai APRA kecamatan Sindang Barang.. Hasil dari deskripsi ini bertujuan untuk menambah wawasan masyarakat tentang keanekaragaman budaya yang ada khususnya perilaku budaya pada masyarakat di Cianjur Selatan.

Mitos kerap dikaitkan dengan penghuni "alam lain" yang berdampingan dengan alam manusia. Mahluk halus sebagai penghuni alam lain dipercaya oleh sebagian masyarakat memiliki kemampuan mempengaruhi perilaku manusia ke arah yang baik atau buruk.

Istilah "alam lain" kerap dihubungkan dengan kepercayaan dari setiap suku bangsa di Indonesia. Suku bangsa Jawa dikenal memiliki agama asli dengan istilah kejawen, suku bangsa Sunda umum dikenal memiliki kepercayaan dengan istilah sunda wiwitan. Agama asli ini telah ada jauh sebelum agama baru Hindu, Budha, Islam, dan Kristen - mulai menanamkan pengaruh keimanan mereka di bumi nusantara.

Konflik memang tidak dilakukan secara terbuka namun hingga saat ini agama asli masih kontinyu berusaha bertahan dan membentuk citra positif agar tidak menjadi sasaran hujatan penyelewengan agama. Subagya menyatakan bahwa agama pendatang itu unggul dalam perlengkapan doktriner, kenegaraan dan lambat-laun berfungsi sebagai ideologi negara di bawah kekuasaan sentral dan sakral. Namun penduduk tetap menganut agama asli sekalipun digolongkan out-group. Di Jawa pada masa Hindu penganut agama asli ini disebut jaba (1981: 237).

Sebenarnya masalah konflik antar umat beragama tidak perlu dilakukan apabila masyarakat mengerti dan mengamati kilas balik sejarah pembentukan Indonesia yang dimulai dari masa kerajaan tradisional.
Kerajaan besar yang ada pada waktu itu, Majapahit, telah menunjukan ketentraman di antara umat beragama seperti yang tertera dalam Kakawin Sutasoma.

Penjelasan dari Kakawin Sutasoma tersebut di atas memang harus diamati dalam menelaah kehidupan agama asli di Indonesia saat ini. Berbagai jenis kepercayaan terhadap "alam lain" hingga saat ini masih sangat dipercaya dapat memberikan pengaruh positif atau negatif bagi masyarakat. Pengaruh positif dapat berupa kelancaran dalam mencari jodoh dan karir, sementara pengaruh negatif adalah sakit yang tidak dapat dijelaskan dari segi ilmu kedokteran modern.

Penelitian ini menggunakan metode kualitatif, yaitu berupaya deskripsi tentang mitos Nyi Roro Kidul di daerah Cianjur Selatan. Analisa data cenderung diarahkan pada sisi etnografi untuk proses klarifikasi dan kategorisasi data yang diperoleh. Oleh karena itu, penggunaan teori dan referensi amat diperlukan untuk mempermudah analisa data. Surbakti (2005: 34) mengatakan bahwa teori dalam penelitian sosial sangat berguna untuk memberikan pola interpretasi data, menghubungkan satu studi dengan lainnya, menyajikan kerangka sehingga konsep dan variabel mendapatkan arti, dan memungkinkan kita menginterpretasikan data yang lebih besar dari temuan yang diperoleh dari suatu penelitian.

Sesuai dengan metode penelitian yang dipilih, yaitu kualitatif, dengan berpedoman pada paparan Oetomo (2005: 186) bahwa data kualitatif dapat dikumpulkan melalui 3 cara, yaitu: wawancara mendalam dan terbuka, observasi langsung, dan penelaahan dokumen tertulis.

Responden dan informan merupakan jenis data primer yang harus dicari dengan spesifikasi yang dapat mengarahkan pada keakuratan data. Spesifikasi yang dimaksud adalah kekayaan informasi dari informan tentang mitos 
Nyi Roro Kidul. Oleh karena itu sebagai wacana pencarian informan pencarian informan mengarah pada tokoh masyarakat baik formal maupun informal. Sementara itu, kriteria responden adalah masyarakat di wilayah pesisir pantai Cianjur Selatan.

\section{B. Hasil dan Bahasan}

\section{Mitos Nyi Roro Kidul dalam Kehidupan Masyarakat Di Cianjur Selatan}

\section{Sekilas tentang Kabupaten Cianjur}

Cianjur salah satu kabupaten di wilayah Propinsi Jawa Barat memiliki letak yang strategis karena dilintasi jalur jalan negara antara Jakarta Bandung. Luas wilayah $350.148 \mathrm{Ha}$ dan memiliki pantai sepanjang $75 \mathrm{Km}$. Kabupaten dibatasi oleh 5 Kabupaten, masingmasing adalah:

- Sebelah utara berbatasan dengan Wilayah Kabupaten Bogor dan Purwakarta,

- Sebelah barat berbatasan dengan wilayah kabupaten Bandung dan Garut

- Sebelah selatan berbatasan dengan Samudera Indonesia.

- Sebelah timur berbatasan dengan Kabupaten Bandung dan Kabupaten Garut.

Pada bagian selatan Kabupaten Cianjur yang berbatasan dengan samudera Indonesia, terdapat wilayah pantai yang memiliki panorama indah dan sekaligus menyimpan misteri tentang keberadaan sosok Nyi Roro Kidul. Akses ke lokasi pantai Apra dari pusat kota kecamatan Sindangbarang sangat dekat, dari alun-alun jaraknya hanya sekitar 600 meter, bisa ditempuh dengan berjalan kaki melewati perkampungan penduduk. Sedangkan dari Cianjur kota, bisa ditempuh menggunakan kendaraan umum maupun pribadi dengan jarak 110 $\mathrm{km}$, melewati beberapa kecamatan.
Sedangkan dari Jakarta diperkirakan jaraknya $220 \mathrm{~km}$. Jarak tempuh yang relatif jauh dengan kontur jalan berkelokkelok membuat perjalanan menuju pantai Apra terasa melelahkan ${ }^{1}$.

Masyarakat di sekitar pantai APRA hanya sedikit yang berprofesi sebagai nelayan. Nelayan di Pantai Apra melakukan kegiatan melautnya dengan bermodalkan sendiri. Nelayan yang ada masih bersifat tradisional, belum ada nelayan yang melakukan penangkapan ikan ke tengah laut dengan perahu atau kapal yang modern. Di Pantai Apra baru ada satu perahu milik warga, namun itupun tidak digunakan ke tengah laut karena memang kondisinya yang tidak memungkinkan. Pantai APRA ombaknya sangat besar dan angin yang cukup kencang sehingga sangat membahayakan keselamatan bagi para nelayan di tengah laut. Selain itu, dipercaya bahwa Pantai Apra adalah salah satu pantai yang masih angker, jangankan melaut ke tengah berenang di pinggir pantai saja tidak boleh saking berbahayanya, lepas dari kepercayaan itu secara logika memang berbahaya karena pantainya sangai curam dan ombaknya besar.

Modal yang mereka pergunakan dalam sekali menangkap ikan tidak terlalu besar sebab menangkap ikannya hanya di sekitar muara pantai saja. Hasil ikan yang mereka peroleh, mereka konsumsi sendiri dan dijual ke pasar. Hasil laut para nelayan di Pantai Apra hanya cukup didistribusikan ke daerah Sindangbarang, Cibinong, dan Cikadu.

\footnotetext{
${ }^{1}$ Selebihnya tentang keelokan pantai lihat, "APRA Pantai Apra Sindangbarang Cianjur 'Saksi' Pemberontakan APRA", dalam Pikiran Rakyat tanggal 15 Maret 2008.
} 


\section{Upacara dan Kesenian untuk Penghormatan Terhadap Nyi Roro Kidul.}

Budhisantoso (1990:7) mengatakan bahwa upacara adalah sebuah tingkah laku resmi bentukan sekelompok masyarakat yangmempunyai kaitan dengan kepercayaan akan adanya kekuatan di luar kemampuan manusia atau kekuatan supernatural, seperti roh nenek moyang pendiri desa, roh leluhur yang dianggap masih memberikan perlindungan kepada keturunannya, dan sebagainya.

Kaitan antara masyarakat di pesisir pantai Cianjur Selatan dengan Nyi Roro Kidul sangat erat. Keeratan tersebut ditandai dengan beberapa upacara yang secara umum ditujukan untuk menghormati keberadaan dan kekuasaan Nyi Roro Kidul atas wilayah pantai mereka. Beberapa temuan upacara tradisional terkait dengan keberadaan Nyi Roro Kidul di pesisir pantai Cianjur Selatan adalah nyalawena, syukuran pasisiran, hajat mulud, babad astana, bebersih cikahuripan, ngaruwat, dan mitembayan panen pare.

\section{a. Nyalawena}

Nyalawena berasal dari salawe, yang artinya dua puluh lima. Kaitan angka tersebut adalah tanggal upacara selalu dilaksanakan setiap tanggal 25 bulan Islam tahun Hijriah.

Pantai APRA, mulai dari hulu sungai hingga garis pantai sejauh $2 \mathrm{~km}$, di Kecamatan Sindangbarang kerap menjadi lokasi Upacara Nyalawena. Selain di Cianjur, upacara ini juga dilaksanakan pada bulan-bulan yang sama seperti di pantai di Garut Selatan. Tradisi ini hingga sekarang masih dilakukan oleh masyarakat terutama di sekitar daerah Rancabuaya dan
Cijayana. ${ }^{2}$ Upacara ini diikuti selain oleh masyarakat sekitar juga dihadiri oleh masyarakat daerah lain yang sebagian besar berasal dari Suku Sunda.

Istilah lain untuk upacara Nyalawena adalah "Ngala Impun" yang artinya menangkap ikan kecil atau impun. Latar belakang pelaksanaan upacara Nyalawena dikaitkan dengan mata pencaharian masyarakat di pesisir selatan yang sebagian besar petani dan peladang. Kondisi cuaca dan keadaan geografis alam pesisir selatan yang tidak ramah mengakibatkan warga kerap mengurungkan niat untuk pergi mencari ikan. Ketakutan akan kondisi alam seputar pesisir selatan membuat warga merasa ada keanehan pada lokasi hunian mereka Tentu saja, sebagaimana daerah lainnya di pesisir selatan pulau Jawa, Nyi Roro Kidul kerap menjadi acuan atas segala kejadian alam yang dialami warga pesisir selatan Kabupaten Cianjur ini.

Mitos Nyi Roro Kidul dalam upacara Nyalawena semakin mengental setelah kemunculan mitos "si pacul". Dikisahkan dalam mitos tersebut tentang seorang pendatang yang bekerja di daerah Sindangbarang. Ia bekerja tanpa mengenal lelah bahkan waktu shalat, termasuk shalat jumat, diabaikannya. Akibat dari kelalaian menghargai waktu shalat, suatu hari pendatang tersebut hilang tanpa jejak. Bukti satu-satunya

\footnotetext{
${ }^{2}$ Menurut masyarakat di sekitar Cijayana dan Rancabuaya, tradisi nyalawena sudah berlangsung sejak dahulu kala. Ketika musim impun tiba, orang dari mana-mana sengaja datang untuk menangkap impun. Jika sudah demikian, muara sungai di sepanjang pantai akan dipenuhi orang dengan berbagai alat yang dibawanya. Biasanya mereka menggunakan sair atau waring (sejenis jaring). Belakangan, dan sering menimbulkan protes, ada orang berburu impun dengan menggunakan tua (racun ikan) dan setrum listrik. Selebihnya, lihat "Nyalawena", dalam http://sunda.web.id/category/adat-istiadat/
} 
bahwa pernah ada pendatang tersebut hanyalah sebuah pacul. Memang agak membingungkan untuk menghubungkan antara kepercayaan masyarakat setempat dengan proses penghukuman karena melanggar waktu shalat yang sejatinya adalah perintah dalam agama Islam. Kaitan satu-satunya adalah menempatkan faktor kesukuan (Sunda) berikut adat istiadat di dalamnya sebagai bagian tidak terpisahkan dengan agama Islam. Aceh juga menganut prinsip serupa yang tercantum dalam pepatah adat ngon hukom lagee dzat ngon sifeut. Pepatah tersebut mengibaratkan adat dan hukum (Islam) sama halnya dengan zat yang tidak lepas dari sifat (zat tersebut). ${ }^{3}$

Kembali pada mitos "si pacul", proses sanksi terhadap seseorang yang melanggar aturan, dalam hal ini "si pacul", secara terus menerus diingatkan dalam bentuk sesaji untuk si pacul. Hal ini juga dipercaya oleh masyarakat bahwa bagi setiap pendatang jangan sampai melanggar pantangan-pantangan karena apabila dilanggar akan terjadi kecelakaan bagi pendatang, terutama pendatang dari Bandung dan sekitarnya. Oleh karena itu, sebelum dilaksanakan Upacara Nyalawena terlebih dahulu harus dilakukan ritual pemberian sesajen kepada Nyi Roro Kidul dan Si Pacul.

Setelah pemberian sesajen kepada Nyi Roro Kidul dan Si Pacul selesai

3 Islam menghargai tradisi. Islam tak selamanya memusuhi tradisi lokal, tetapi justru menjadi sarana vitalisasi nilai-nilai Islam sebab nilai-nilai Islam perlu kerangka yang akrab dengan kehidupan pemeluknya. Islam yang berkembang adalah Islam yang mampu berdialog dengan tradisi lokal, seperti diangkat Alquran dan masa awal kedatangan Islam. Kalau saat ini ada masjid yang bentuknya seperti pura, merupakan sebagai hasil interaksi dengan budaya lokal. Lebih lanjut lihat Toto Suparto, “'Ngalap Berkah' pada Garebek Maulud", dalam Media Indonesia, Sabtu 7 April 2007 halaman 8. dilaksanakan, selanjutnya adalah upacara pokok, yaitu Nyalawena, baru digelar. Masyarakat memiliki hasrat cukup besar untuk mengikuti upacara Nyalawena karena pelaksanaan hari adalah bertepatan dengan bulan-bulan Rajab, Mulud, atau pada Peringatan Hari Besar Islam yang memang diyakini bertepatan dengan kedatangan ikan dalam jumlah besar di wilayah laut sindangbarang. Ada kepercayaan bahwa tradisi nyalawena telah tiba ketika terdengar guntur dari tengah samudra. Suara guntur itu dipercaya sebagai awal dari menetasnya telurtelur ikan yang kemudian bertumbuh menjadi impun. Konon siklus ini terjadi hampir sepanjang tahun, terutama pada bulan-bulan transisi dari kemarau ke musim hujan atau sebaliknya. Awalnya, ikan yang hidup di sungai membiarkan telurnya hanyut sampai ke tengah laut. Ketika telur-telur ini menetas, maka anak-anak ikan yang disebut impun itu secara naluriah akan kembali ke habitatnya di sungai. Siklus ini mirip dengan proses perkembang-biakan ikan Salem di daratan Amerika.

Saat ini di sela-sela kegiatan upacara Nyalawena ditemukan kebiasaan mencari jodoh di kalangan muda mudi. Meskipun demikian, ritual "si pacul" tampak cukup berhasil sehingga saat upacara nyalawena berlangsung tampak tidak ada kegiatan-kegiatan yang melanggar susila, walaupun kemungkinan tersebut terbuka lebar dengan banyaknya muda-mudi yang mengikuti upacara ini. Apalagi pelaksanaan upacara ini biasanya berlangsung sampai malam hari.

Sayangnya, tradisi nyalawena tersebut mulai ditinggalkan masyarakat setempat, terutama kaum muda. Tradisi nyalawena ini sekarang sudah jarang dilakukan oleh kaum muda. Yang masih tetap teguh melaksanakan tradisi ini, kata mereka hanyalah orang-orang tua yang 
kukuh mempertahankan tradisi. Padahal, tradisi itu telah dilakukan selama bertahun-tahun di daerah tersebut. Biasanya masyarakat menangkap impun, ditandai dengan suara gemuruh dari laut dan sudah berlangsung puluhan tahun.

\section{b. Syukur Pasisiran}

Nama Syukur Pasisiran berasal dari dua kata, yaitu kata syukur yang berarti 'rasa syukur' dan pasisiran yang berarti 'daerah yang berada di sekitar pantai'. Jadi, syukur pasisiran secara harfiah berarti rasa syukur masyarakat yang berada di sekitar pantai.

Syukur pasisiran diadakan masyarakat Sindangbarang sebagai ungkapan rasa syukur atas nikmat yang diberikan oleh Tuhan Yang Maha Kuasa. Selain itu, ungkapan rasa syukur juga ditujukan kepada penguasa laut selatan, Nyi Roro Kidul, yang telah berkenan memberikan limpahan hasil panen serta keselamatan nelayan baik selama berada di laut maupun aktivitas yang dilakukan di sekitar pantai.

Tanggal pelaksanaan syukur pasisiran saat ini hanya mengikuti kalender hari besar baik daerah (Cianjur) maupun nasional. Oleh karena itu kadang acaranya diadakan dalam rangka Hari Jadi Kabupaten Cianjur atau Hari Ulang Tahun Republik Indonesia.

Tempat pelaksanaannya pun kadang-kadang di beberapa pantai. Selain pantai APRA, daerah pantai lainnya di Cianjur Selatan yang pernah menyelenggarakan syukur pasisiran adalah Pantai Sereg, Pantai Jayanti, atau di Pantai Batu Kukumbung. Pantai Apra setidaknya pernah diselenggarakan dua kali syukur pasisiran, yaitu tahun $2003^{4}$

\footnotetext{
${ }^{4}$ Pelaksanaan syukur pasisiran tahun 2003 bertepatan dengan kalender pariwisata Kabupaten Cianjur. Oleh karena itu, upacara syukur pasisiran lebih banyak didominasi oleh peragaan berbagai
}

dan 2006. Pelaksanaan di tahun 2006 tidak disertai dengan pelarungan persembahan ke tengah laut karena ombak sangat besar sehingga persembahan hanya dilakukan di bibir pantai saja.

$$
\text { Pelaksanaan upacara syukur }
$$
pasisiran terdiri dari beberapa tahap. Pertama-tama para nelayan atau masyarakat sekitar menyiapkan semua persembahan atau perlengkapan upacara, baik dengan cara sumbangan maupun membuat sendiri. Biasanya untuk pengadaan barang-barang yang membutuhkan biaya besar, selalu ditanggung bersama, seperti kepala kerbau. Sedangkan barang-barang kecil yang tidak membutuhkan biaya besar, dikumpulkan dari perorangan. Semua persembahan yang telah tersedia disiapkan di suatu tempat, biasanya di halaman rumah juru kunci, tokoh masyarakat yang akan memimpin jalannya upacara.

Pagi hari yang sudah ditentukan untuk memulai upacara, masyarakat berbondong-bondong mengarak persembahan ke bibir pantai untuk diberikan doa-doa, melakukan doa bersama, selanjutnya pergi ke laut dengan perahuperahu yang penuh dengan persembahan. Itu pun dilakukan kalau bisa melaut,

jenis kesenian tradisional seperti tari nyalawena, seni reak, tanjidor, dan rengkong. Sukur Pesisir sendiri, akan terus berlangsung sepanjang tahun 2003, setelah di Cianjur, pantai Sindang Barang (17-20 Mei), akan beralih ke Ciamis pantai Pangandaran (30-31 Mei dan 1 Juni), Cirebon, Pantai Mundu (10-17 Juli), Subang, pantai Blanakan (1-7 September), Karawang, Pantai Tanjung pakis (19-21 September), Indramayu, pantai Song (1-7 Oktober), Garut, pantai Cialit Eureun (10-12 Oktober) dan Tasikmalaya, pantai Pamayangsari (16-22 Oktober). Lebih lanjut, lihat Matdon, "Sisi Lain dari Sukur Pesisiran 2003: Geliat Tradisi Pesisir di Pantai Apra", dalam Sinar Harapan tahun 2003, atau http://www.sinarharapan.co.id/hiburan/budaya/ 2003/0524/bud2.html 
tetapi kalau tidak bisa ke tengah laut, cukup di bibir pantai saja.

\section{c. Ngaruwat}

Ngaruwat adalah upacara yang bertujuan untuk memohon keselamatan kepada Tuhan Yang Maha Kuasa serta pada para karuhun yang termasuk di dalamnya adalah penguasa pantai selatan - yaitu Nyi Roro Kidul. Prosesi ngaruwat sebenarnya hampir berlaku umum di setiap suku bangsa di Indonesia. Salah satunya dilakukan pada masyarakat Aceh yang disebut dengan istilah peusijuek ${ }^{5}$. Sama halnya pola life cycle dalam agama Islam juga sering ditindaklanjuti dengan upacara selamatan.

Ngaruwat biasanya dipimpin oleh seorang juru ruwat atau orang yang ahli dalam ngaruwat, bisa dari tokoh masyarakat atau tokoh ulama yang telah biasa melaksanakannya. Upacara ini bisa diikuti oleh masyarakat umum atau cuma oleh orang-orang tertentu saja. Kalau yang diruwatnya tempat-tempat umum biasanya diikuti oleh masyarakat umum, sedangkan kalau yang diruwatnya tempat-tempat pribadi (tertentu) hanya diikuti oleh orang-orang tertentu, terutama orang yang mempunyai hajat.

\section{Antara Kanjeng Ratu Kidul dengan Nyi Roro Kidul}

Dua nama yang menurut mata masyarakat awam adalah sama antara Kanjeng Ratu Kidul dengan Nyi Roro Kidul. Pandangan ini akan sangat berbeda dengan pakar yang membidangi

5 Peusijuek dapat digelar dalam bentuk upacara sederhana maupun berskala besar. Inti dari upacara peusijuek adalah memohon keselamatan dari orang yang berkepentingan terhadap benda, barang, karir, dan perkawinan. Tahapan sederhana adalah pembacaan doa dari teungku yang dilanjutkan dengan suapan nasi kuning dari teungku. Setelah itu, teungku memercikan air dengan menggunakan tiga tangkai dari tiga jenis tanaman. masalah mitologi ataupun paranormal yang kerap bersentuhan dengan dunia gaib. Ternyata ada kekeliruan besar yang selama ini dibiarkan terjadi yaitu menyamakan antara Kanjeng Ratu Kidul dengan Nyi Roro Kidul.

Masyarakat Cianjur selatan tampak tidak begitu paham akan perbedaan kedua nama tersebut (Kanjeng Ratu Kidul dan Nyi Roro Kidul). Kepastian yang ada hanya penghormatan terhadap sosok yang menguasai wilayah tempat mereka menetap dan mencari nafkah sebagai petani dan nelayan - serta memberikan sesaji melalui upacara Nyalawena ataupun syukur pasisiran dan Ngaruwat kepada sosok tersebut. Apalagi beberapa informan yang ditemui tidak ada satupun yang pernah menemui kejadian aneh yang berkaitan dengan perjumpaan dengan sosok penguasa laut selatan tersebut, meskipun di daerah lain telah terjadi keanehan yang merujuk pada pertemuan antara seseorang atau berkelompok dengan Nyi Roro Kidul.

Pengkaburan atas dua nama ini mengarah pada awal pengkultusan sosok Kanjeng Ratu Kidul yang memang berasal dari tanah Jawa. Dapat dikatakan bahwa masyarakat awam di Tanah Parahyangan tidak begitu membedakan antara Kanjeng Ratu Kidul dengan Nyi Roro Kidul karena keduanya adalah sama-sama sebagai sosok penguasa laut selatan. Meski demikian, keyakinan akan adanya sosok penguasa pantai selatan hingga saat ini masih ada. Apalagi para sesepuh adat Sunda di Cianjur Selatan yang memang telah dibekali pengetahuan supranatural hingga mampu melihat melalui batin terhadap berbagai gejala alam dari sudut pandang gaib.

Kemampuan dalam menelaah dunia gaib para sesepuh adat Sunda bukan datang dengan sendirinya. Fenomena agama asli Sunda wiwitan patut menjadi bahan referensi untuk 
mengetahui keberadaan sosok penguasa pantai selatan daerah parahyangan ini.

Upaya agar penguasa pantai selatan tidak membuat kerusakan terhadap wilayah tempat tinggal dan mata pencaharian masyarakat Cianjur Selatan kerap diadakan dalam bentuk pemberian sesaji dalam upacara Nyalawena, syukur pasisiran, dan ngaruwat yang diadakan setiap tahun. Oleh karena itu, setiap ada tanda - terutama gejala alam di lautan seperti halilintar yang bersahut-sahutan disertai dengan gelombang besar merupakan salah satu pertanda akan datang kemurkaan dari sang penguasa laut selatan.

Tanda-tanda alam yang diamati dan dianalisis masyarakat Cianjur Selatan hingga menuju pada kesimpulan bahwa kemurkaan alam disebabkan ulah penguasa laut selatan menunjukan keeratan hubungan masyarakat Cianjur Selatan terhadap lingkungan sekitar. Hal ini menurut Peter L. Berger \& Thomas Luckmann didasarkan dorongan biologis manusia untuk terus bersentuhan timbal balik dengan lingkungan. Di lain pihak pola persentuhan tersebut terkait dengan budaya yang membungkus manusia agar mengikuti prosedur tertentu sehingga tercapai unsur keseimbangan perilaku manusia dalam memanfaatkan alam lingkungan. ${ }^{6}$

Sesaji sebagai salah satu produk budaya yang lekat dengan unsur kepercayaan kerap selalu disediakan dalam setiap upacara. Upacara Nyalawena, Syukur Pasisiran, dan Ngaruwat juga wajib menggunakan sesaji. Terutama sesaji sebagai suguhan kepada penguasa lautan selalu disertakan kepala kerbau seperti dalam upacara Nyalawena. Di Pangandaran ada istilah

${ }^{6}$ Peter L. Berger \& Thomas Luckmann, "Tafsir Sosial atas Kenyataan: Risalah tentang Sosiologi Pengetahuan", Makalah, hal. 69 - 70 dongdang, yaitu sesaji yang ditaruh dalam sebuah kotak. Di antara jenis sesaji tersebut terdapat sebuah kepala sapi jantan, seperangkat peralatan wanita lengkap mulai dari sanggul, alat rias, sampai pakaian dalam, bubur merah, bubur putih, rujak, dan lainnya. Pemberian warna merah dan putih pada sesaji bubur hanyalah sebagai simbol bendera negara Indonesia.

Bentuk sesaji sebagai suguhan tersebut tidak lebih dari upaya balas jasa, pamrih atas apa yang telah diberikan ataupun kemurahan hati dari sosok penguasa laut selatan tersebut. Dari pandangan antropolog, diistilahkan pemberian tersebut sebagai bentuk resiprositas (pertukaran) yaitu pemberian kepada seseorang yang telah memberi sesuatu (barang atau jasa). Bentuk resiprositas ini dalam prosesnya mengarah kepada sistem upeti atau pemberian yang wajib diberikan kepada seseorang yang dianggap berkuasa. Apabila pemberian tidak dilakukan maka akan timbul kemarahan dari sang penguasa tersebut dalam bentuk pengrusakan harta benda atau kesengsaraan kepada seseorang atau sekelompok orang.

\section{Keberadaan Nyi Roro Kidul di Cianjur Selatan: Antara Fakta dan Mitos}

Dikatakan dalam banyak cerita dan legenda bahwa Nyi Roro Kidul sebagai sosok gaib penguasa laut selatan pulau Jawa. Penampakan dalam bentuk kejadian ataupun lewat mimpi tentang Nyi Roro Kidul yang ditindaklanjuti dalam bentuk kebiasaan melakukan upacara sebagian besar terkonsentrasi pada lokasi-lokasi tertentu. Di wilayah Jawa Tengah, Yogyakarta, dan Jawa Timur, upacara penghormatan kepada Nyi Roro Kidul terpusat di Provinsi Yogyakarta, tepatnya di pantai Parangtritis. Di Provinsi Jawa Barat, 
Mitos yang ditindaklanjuti dalam bentuk upacara untuk menghormati Nyi Roro Kidul juga terkonsentrasi pada lokasi atau tempat tertentu saja. Peta administratif Provinsi Jawa Barat bagian selatan yang berbatasan dengan bibir pantai terbagi dalam beberapa kecamatan seperti yang tertera dalam tabel di bawah ini.

\section{Tabel 1}

Kecamatan dalam wilayah pesisir Selatan Jawa Barat

\begin{tabular}{|c|c|c|c|c|}
\hline Ciamis & $\begin{array}{c}\text { Tasikmala } \\
\text { ya }\end{array}$ & Garut & Cianjur & Sukabumi \\
\hline $\begin{array}{c}\text { Kali- } \\
\text { pucang }\end{array}$ & Cikalong & $\begin{array}{l}\text { Mekar- } \\
\text { mukti }\end{array}$ & Cidaun & $\begin{array}{c}\text { Tegalbuleu } \\
\mathrm{d}\end{array}$ \\
\hline $\begin{array}{c}\text { Penganda } \\
\text { ran }\end{array}$ & $\begin{array}{c}\text { Karangnun } \\
\text { ggal }\end{array}$ & Caringin & $\begin{array}{c}\text { Sindangbar } \\
\text { ang } \\
\end{array}$ & Surade \\
\hline Cijulang & $\begin{array}{l}\text { Bantar } \\
\text { Kalong }\end{array}$ & Bungbulang & Agrabinta & Сiгасар \\
\hline Sidamulih & Cipatujah & Pakenjeng & - & Ciemas \\
\hline Cimerak & - & Cikelet & - & $\begin{array}{c}\text { Pelabuhanr } \\
\text { atu }\end{array}$ \\
\hline- & - & $\begin{array}{c}\text { Pamengp } \\
\text { euk }\end{array}$ & - & Cibitung \\
\hline- & - & Cibalang & - & Cikakak \\
\hline- & - & & - & Cisolak \\
\hline
\end{tabular}

Sumber: Diolah dari berbagai sumber.

Di lima kabupaten yang tertera pada tabel di atas tampak hanya ada beberapa kecamatan saja yang santer menyorot keberadaan Nyi Roro Kidul, yaitu pangandaran (Ciamis), Sindangbarang (Cianjur), dan Pelabuhanratu (Sukabumi) ${ }^{7}$. Dengan demikian, timbul keraguan apakah benar Nyi Roro Kidul adalah benar penguasa seluruh pantai bagian selatan Pulau Jawa? Selain itu, mengapa Nyi Roro Kidul hanya berkuasa di bagian selatan

7 Asal usul nama pelabuhanratu berkaitan erat dengan Nyi Roro Kidul. "Ratu" pada nama Pelabuhanratu adalah tidak lain dari Ratu Kidul yang berlabuh di tempat yang saat ini bernama pelabuhan ratu.
Pulau Jawa? Selain itu, ada wacana yang membedakan antara Nyi Roro Kidul dengan Kanjeng Ratu Kidul. Apakah ada perbedaan atau hanya sekedar istilah yang berbeda sementara individu yang dituju adalah satu orang saja?

Kisah Nyi Roro Kidul ada kesamaan dengan kisah Batara Baruna dalam dunia pewayangan dan kisah Poseidon dalam mitologi Yunani Kuno. Ketiga kisah tersebut mengkultuskan satu sosok sebagai penguasa lautan. Ketiganya memiliki kewenangan untuk menjadikan lautan tenang, berombak, bahkan tsunami.

\section{Gambar 2}

Batas-batas fisik wilayah pesisir pantai Cianjur selatan

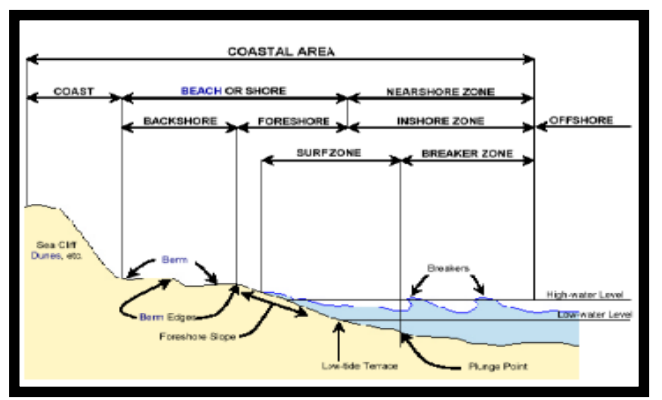

Sumber: Brahtz, 1972

Faktor geografis Pantai Sindangbarang memang sangat berpotensi menimbulkan gelombang besar yang sangat membahayakan para nelayan. Dengan demikian, dari segi fakta telah tampak kaitan dengan mitos. Apalagi setelah menyimak kondisi pantai dan laut selatan Pulau Jawa secara keseluruhan. Eko Yulianto, ${ }^{8}$ seorang peneliti dari Lembaga Ilmu Pengetahuan

8 Lihat, Hubungan Bencana Tsunami dengan Legenda Nyi Roro Kidul, dalam http://kumpulan-artikelmenarik.blogspot.com/2008/11/hubunganbencana-tsunami-dengan-legenda.html 
Indonesia (LIPI), mengatakan bahwa kawasan pantai selatan, berhadapan dengan Samudera Indonesia, yaitu daerah zona subduksi ${ }^{9}$ lempeng bumi. Indonesia yang merupakan sebuah negara kepulauan sangat subur adalah hasil dari proses subduksi yang berlangsung secara terus menerus. Walaupun telah berbentuk kepulauan, proses subduksi masih terus berlanjut dan melalui proses itu pula yang memberikan berbagai bencana, letusan gunung berapi, gempa bumi, dan tsunami seperti yang telah ataupun sedang terjadi di Indonesia saat ini.

Telaah keberadaan Nyi Roro Kidul di antaranya adalah melalui gambar atau lukisan yang saat ini banyak dicetak di berbagai mass media. Di antara lukisan tersebut sebagian besar terpampang sosok Nyi Roro Kidul saat mengendalikan kereta kuda di tengah gelombang laut yang sangat besar.

Gelombang besar dalam lukisan Nyi Roro Kidul apabila terjadi dalam kenyataan bencana di Indonesia tentu akan banyak menelan korban jiwa. Setelah terbawa arus laut korban kemudian terbawa arus balik dan terdampar kembali di pantai.

Herry Harjono, Kepala Pusat Penelitian Geoteknologi LIPI, mengatakan bahwa sangat aneh untuk mengkaitkan legenda atau mitos Nyi Roro Kidul dengan sejarah tsunami di Indonesia. Walaupun demikian, Harjono mengatakan bahwa "bantuan ilmuwan sosial untuk mengungkap asal-muasal legenda itu juga diyakini bisa membantu penelitian sejarah kejadian tsunami."

Melalui mitos Nyi Roro Kidul setidaknya akan memperkuat data para geolog dalam mencari jejak tsunami purba, seperti mengenai bukti gempa dan

9 Subduksi ialah proses menghujamnya lempeng benua yang bermassa lebih besar ke lempeng benua yang ada di bawahnya. endapan tsunami yang terjadi pada 400 tahun lalu di Cilacap dan Pangandaran yang diyakini jauh lebih besar ketimbang yang terjadi pada 2006. Pasca tsunami yang telah melanda pantai di Cilacap dan Pangandaran tahun 2006 lalu masih menyisakan rasa was was para penduduk yang bermukim dekat pantai. Di Cilacap rasa was was saat itu masih sangat terasa apalagi saat muncul pesan pendek via handphone (SMS) yang mengabarkan bahwa tsunami akan terjadi selasa kliwon. Gelar ritual larung kepala kerbaupun segera dilaksanakan di pantai Teluk Penyu Cilacap pada hari senin tanggal 31 Juli 2006. ${ }^{10}$

Endapan pasca tsunami juga telah membentuk semacam endapan tsunami di tebing sungai Cimbulan Pangandaran. Salah satunya berupa lapisan pasir tebal hingga $20 \mathrm{~cm}$ yang diendapkan di atas lumpur mangrove dan ditutupi endapan banjir. Oleh karena itu, hutan mangrove (bakau) seperti tertera di atas kerap dijadikan lokasi semedi untuk memohon sesuatu kepada Nyi Roro Kidul. Dalam endapan juga ditemukan pasir yang mengandung cangkang "fora minifera" seperti yang biasa hidup di laut lepas. Analisis pentarikhan umur terhadap dua sampel yang diambil dari dua tempat berbeda menunjukkan lapisan pasir tsunami itu diendapkan 400 tahun lalu.

Petunjuk endapan yang sama pasca tsunami di Indonesia juga ditemukan di sepanjang pantai daerah Majene, Lombok, Mentawai, dan Simeulue. Khususnya di Simeulue - sebuah pulau di barat daya Provinsi NAD rupanya telah mengenal tanda-tanda pra tsunami dengan istilah smong. Smong memuat pesan sederhana, namun masih dipatuhi warga Simeulue. Pesan itu berbunyi:

${ }^{10}$ Eviyanti, "Rasa Was Was Hantui Warga Pesisir", dalam Pikiran Rakyat 31 Juli 2006, hal. 7. 
"Jika terjadi gempa bumi kuat diikuti oleh surutnya air laut, segeralah lari ke gunung karena air laut akan naik". Pengetahuan tradisional itu muncul setelah tsunami 1907. Disebutkan, seringnya tsunami sebelum 1907 di pulau itu memiliki andil bagi bersemainya pengetahuan tersebut. Catatan sejarah dan penelitian geologi menunjukkan pulau itu terlanda tsunami pada 1797 , 1861, dan 1907.

\section{Penutup}

\section{Kesimpulan}

Bermula dari proses adaptasi manusia dengan alam secara kontinyu. Manusia mengamati dan menterjemahkan gejala alam hingga akhirnya menemukan solusi - atas pertanyaan-pertanyaan yang diberikan oleh lingkungan sekitar - berdasarkan tingkat pengetahuan pada masa itu. Agama asli adalah jawaban atas segala pertanyaan yang menyelimuti manusia atas gejala alam yang dialaminya.

Terutama agama asli yang berwujud animisme, saat ini masih tetap bertahan di Indonesia yang disebut dengan kepercayaan. Di Pulau Jawa, kelompok besar kepercayaan yang ada mengandung paham kejawen dan sunda wiwitan. Dan, keduanya sama-sama menaruh rasa hormat atas keberadaan Nyi Roro Kidul sebagai sosok penguasa laut selatan.

Ada perbedaan paham antara penamaan Nyi Roro Kidul dengan Kanjeng Ratu Kidul. Masyarakat sukubangsa Jawa memberikan status tertinggi kepada Kanjeng Ratu Kidul sementara Nyi Roro Kidul adalah salah satu patih yang tidak disukai Kanjeng Ratu Kidul karena memiliki sifat iri dan dengki. Ketidaksukaan tersebut diwujudkan dalam bentuk pengusiran terhadap Nyi Roro Kidul. Nyi Roro Kidul akhirnya membuat istana sendiri di daerah
Parangtritis dengan wilayah kekuasaan di sepanjang pantai selatan Pulau Jawa.

Masyarakat Sunda tidak begitu paham dengan perbedaan tersebut karena menganggap keduanya (Kanjeng Ratu Kidul dan Nyi Roro Kidul) adalah sama, yaitu samasama sebagai penguasa laut selatan.

Paham yang sama juga dianut oleh masyarakat Cianjur Selatan. Masyarakat Cianjur selatan memberikan rasa hormat kepada Nyi Roro Kidul dalam bentuk pelaksanaan upacara seperti Nyalawena, Syukuran Pasisiran, dan Ngaruwat. Sementara itu, ada juga beberapa pantangan yang harus ditaati berkaitan dengan ketidaksukaan Nyi Roro Kidul atas beberapa hal tertentu. Mitos "Si Pacul" adalah salah satu contoh sebagai sosok penderita, yang terkena tumbal atas perilaku yang telah melanggar larangan Nyi Roro Kidul. Mitos ini secara kontinyu diperingati dalam setiap upacara Nyalawena.

Mitos yang merupakan produk budaya bukanlah tidak dibuat begitu saja oleh para leluhur tanpa ada makna bukti dari kebenaran yang melandasinya. Saat ini mitos kurang begitu berarti bagi masyarakat. Mereka hanya sebatas tahu tanpa menganalisa makna yang terkandung dalam mitos tersebut. Analisa mitos dapat dilakukan dengan bersandarkan pada kondisi fisik suatu daerah dan etika kekinian. Analisa mitos Nyi Roro Kidul sebagai penguasa pantai selatan lebih banyak didasarkan pada kondisi fisik pantai selatan Pulau Jawa. Telah dibuktikan bahwa ada kaitan - meski tidak terlalu signifikan - antara kemarahan Nyi Roro Kidul dengan sejarah gelombang besar, atau bahkan tsunami, yang melanda terutama di sepanjang pantai selatan, termasuk di Cianjur Selatan tentunya. 


\section{Saran}

Mitos tentang Nyi Roro Kidul di Cianjur Selatan, berdasarkan penelitian ini, ternyata bukan sekedar isapan jempol belaka. Meski dari pemikiran kekinian tidak tampak sosok jelas Nyi Roro Kidul namun makna etika yang terkandung di dalam mitos ini patut untuk difikirkan kembali. Terdapat banyak etika positif yang dapat diambil berkaitan dengan unsur pelestarian lingkungan serta interaksi antar individu ataupun dengan sekelompok masyarakat.

Upaya pelestarian kebudayaan yang saat ini tengah gencar dilakukan sangat terkait dengan penggalian potensi wisata tiap daerah. Terkadang segi mitos hanya sebagai unsur pendukung yang tidak memiliki makna sosial sama sekali. Beberapa pantangan dalam mitos sering dilanggar terutama oleh wisatawan. Oleh karena itu, disarankan agar mitos-mitos yang ada terutama di daerah kunjungan wisata budaya patut dilestarikan karena berkaitan erat dengan pelestarian lingkungan dan keserasian tatanan sosial masyarakat di lingkungan daerah wisata.

\section{DAFTAR PUSTAKA}

Chambers, R. 1996.

P.R.A.-Participatory Rural Appraisal, Memahami Desa Secara Partisipatif. Yogyakarta: Kanisius.

Chambers, R. 1999.

"Relaxed and Participatory Appraisal: Notes on Practical Approaches and Methods, Notes for Participant", dalam P.R.A. Familiarization Workshop. Brighton: Institute of Development, Studies University of Sussex, hlm. 1-23.

Driya Media Berbuat Bersama Berperan Serta. 1996.

Acuan Penerapan Participatory Rural Appraisal. Bandung.
Koentjaraningrat. 1993.

Manusia dan

Indonesia. Jakarta: Jambatan.

Rosyadi et al. 2007.

Nilai-Nilai Budaya Dalam

Pelestarian Lingkungan Hidup Di

Wilayah Budaya Priangan Barat

(Kabupaten Cianjur). Jakarta:

Depbudpar.

Subagya, Rachmat. 1981. Agama Asli Indonesia. Edisi II Jakarta: Sinar Harapan.

Surbakti, Ramlan A. 2005.

"Teori dalam Penelitian Ilmu Sosial", dalam Bagong Suyanto dan Sutinah (ed) Metode Penelitian Sosial: Berbagai Alternatif Pendekatan. Jakarta: Kencana.

Syam, Nur. tth

Islam Pesisiran dan Islam

Pedalaman: Tradisi Islam Di

Tengah Perubahan Sosial. Makalah

Fakultas Dakwah IAIN Sunan Ampel.

Umam, Fawaizul. tth

Mengurai Ketegangan Islam dan Lokalitas dengan Etnoher-meneutik. Makalah. Mataram: IAIN.

"'Seren Taun', Melestarikan Budaya Asli Sunda", 2003, dalam Kompas, Sabtu, 05 April.

\section{Sumber Elektronik}

"Alam Mahluk Halus", dalam www.merbabu.com

"Jumlah Penduduk Kabupaten Cianjur Tahun 2004", dalam http://www. cianjur.go.id/Ver.2.0/Content_ Nomor_Menu_18_3.html

"Nyalawena", dalam http://sunda.web.id/ category/naskah-sunda/nyalawena

"Nyalawena", Tradisi Mencari 'Impun' Masyarakat Sindangbarang, dalam www.compas.co.id. 

Patanjala Vol. 1, No. 2, Juni 2009: 188 - 200 